\title{
Intrapair birthweight discordance in twins
}

\author{
Alphonsus N. Onyiriuka \\ Department of Child Health, University of BeninTeaching Hospital, P.M.B 1111, Benin City, Nigeria
}

Page $\mid 110$

Correspondence to: Dr. Alphonsus N. Onyiriuka, University of Benin Teaching Hospital, P.M.B 1111, Benin City, Nigeria. E-mail: alpndiony@yahoo.com

\begin{abstract}
Background: Birthweight differences in twin pairs influence their perinatal outcome as well as growth and development. Growth-discordant twins have not been well characterized in our local environment.

Objective:To determine the frequency of birthweight discordance in live-born twin pairs and document some factors that may influence it.

Methods: In this cross-sectional study, 104 live-born twin pairs were recruited and their intrapair birthweight differences were determined. Twin pairs whose birthweight difference was $15 \%$ or more, using the larger infant as the growth standard, were designated as discordant. The maternal age, parity, and birth order of the heavier twin were noted.

Results: The prevalence of birthweight discordance was $28.8 \%$ when a $15 \%$ cut-off point was used but dropped to $9.6 \%$ when a $25 \%$ cut-off point was applied. Grand multiparity was associated with a significantly increased risk of delivery of discordant twins. Same-sex twin pairs accounted for $60 \%$ of all cases of birthweight discordance. Conclusion: Birthweight discordance is common in twin gestations in Benin City, especially among grand multiparous women.
\end{abstract}

Keywords: Birthweight discordance, growth discordance, twins

\section{Résumé}

arrière-plan: Birthweight différences entre les paires de jumeaux influencent leurs issue périnatale, ainsi que croissance et le développement. Croissance déplacés jumeaux n'ont pas été bien caractérisé en notre environnement local. objectif: à déterminer la fréquence de divergence de birthweight en paires de jumeaux nés en direct et document de certains facteurs qui peuvent influencer prononce

méthodes: en Cette étude transversale, 104 jumeauxnés en direct paires ont été recrutés et leurs intrapair birthweight différences ont été déterminés. Twin paires dont birthweight différence était de $15 \%$ ou plus, en utilisant le bébé plus grand que la norme de croissance ont été désigné comme déplacés. L'ordre d'âge, la parité et la naissance maternelle de la twin plus lourd ont été notées.

résultats: La prévalence de la divergence de birthweight était 28,8\% lorsque point de coupure de $15 \%$ a été utilisé mais ignorés à 9,6\% lors de point de coupure de $25 \%$ a été appliquée. Grand multiparity était associé à un risque considérablement accru de la livraison de déplacés jumeaux. Les paires de jumeaux de même sexe représentaient $60 \%$ de tous les cas de birthweight divergence.

conclusion: Birthweight divergence est courante dans twin gestations dans la ville de Bénin, en particulier Parmi les grands femmes multiparous.

Mots cles: Jumeaux, birthweight divergence, croissance divergence

DOI: $10.4103 / 1596-3519.56239$

PMID: 19805942 


\section{Introduction}

Birthweight discordance is a common growth problem in twin gestations, with varying frequency depending on the definition used. ${ }^{[1]}$ The threshold for clinically significant discordance has been variably defined as $15 \%{ }^{[1,2]}$ and $25 \%,{ }^{[3]}$ respectively. Using a birthweight difference of more than $25 \%$ as a cutoff point, Blickstein et al, compared two cohorts of twin pairs, one from four different perinatal centers (United States, Poland, and two from Israel) and the other from a Swedish population-based data; they found birthweight discordance of $11 \%$ in the former and $12 \%$ in the latter. ${ }^{[3]}$ Some investigators have reported that divergent fetal growth increases the risk of fetal death ${ }^{[2,4,5]}$ and other adverse outcomes such as prematurity ${ }^{[4,6]}$ with its attendant morbidity and mortality. In a study of 122 live-born twin pairs delivered between 25- and 34-week gestation, Cheung et al. ${ }^{[7]}$ reported that birthweight discordance greater than $30 \%$ was associated with congenital anomalies and complications of prematurity. Both physical and intellectual followup examinations have shown that a discordant twin was at a disadvantage. ${ }^{[8]}$

In view of the potential adverse outcomes that may be associated with the phenomenon of growth discordance in twins, participants of an international census survey recommended that every twin gestation should be evaluated for growth discordance and, when diagnosed, should be observed very closely. ${ }^{[9]}$

Growth-discordant twins have not been well characterized in our local environment. In fact, there are statements in the literature indicating that even in developed countries growth-discordant twins are poorly characterized,,$^{[1,4]}$ suggesting global paucity of information on the subject.

The present study sought to determine the frequency of birthweight discordance in twin gestations in Benin City and document some of the factors that may influence it.

\section{Materials and Methods}

This descriptive (cross-sectional) study was conducted in a Nigerian mission hospital in Benin City. The hospital, St. Philomena Catholic Hospital $(\mathrm{SPCH})$, has a large maternity unit with an average of 1,344 deliveries annually. ${ }^{[10]}$

During the 4-year study period January 1, 2000 to December 31,2003 all twin babies delivered at SPCH were weighed naked by a trained midwife, within the first $30 \mathrm{~min}$ after birth, using a rotational balance made by Waymaster, England, and calibrated to the nearest $50 \mathrm{~g}$. This scale was checked periodically with known weights for reliability and daily for zero error to ensure accuracy. The weights, birth order, and sexes of the babies as well as their corresponding maternal ages and parity were recorded.

In the present study, a twin pair was designated discordant if one of the pairs was smaller by $15 \%$ or more. The level of discordance was calculated for each pair as a percentage of the birthweight of the heavier twin [discordance $(\%)=100$ (birthweight difference/birthweight of heavier twin)]. Intrapair birth-weight percentage differences were stratified into the following categories: $15-24.9 \%, 25-34.9 \%$, and $35 \%$ or more, which roughly corresponded to moderate, severe, and extreme discordance, respectively. The percentage difference in birthweight of $<15 \%$ was regarded as the mild level of discordance. Twin pairs were called discordant first or discordant second depending on whether the smaller one was first- or second-born, respectively. In this study, a woman was accepted as primiparous if her parity was zero, multiparous if her parity was $1-4$, and grand multiparous if her parity was 5-9.

Only live-born twin pairs who weighed $500 \mathrm{~g}$ or more were included in the data analysis. Twin pairs were excluded if one or both were stillborn.

Statistical analysis involved the test of significance using Student's t-test for mean and Z -test for proportions with the level of significance set at $P$ $<0.05$.

\section{Results}

A total of 115 women with twin gestations were delivered during the 4- year study period and they accounted for $2.5 \%$ of all deliveries in the hospital. In eight twin gestations, one fetus per pair was stillborn, while both fetuses were stillborn in an additional three twin gestations. The remaining 104 women delivered of live-twin pairs whose data were further analyzed.

In the present study, using 15\% birthweight difference as a cut-off point, the overall incidence of birthweight discordance in twins was $28.8 \%$. The incidence dropped to $9.6 \%$ when a $25 \%$ cut-off point was applied. Of the 30 discordant pairs (using $15 \%$ cut-off point), 14 (46.7\%) and $16(53.3 \%)$ were discordant first- and discordant-second respectively, $Z$-statistic $=0.515 ; \mathrm{P}>0.05$. Comparing the mean birthweight of discordant-first and discordantsecond pairs, it was $1973 \mathrm{~g}$ (95\% confidence interval, $\mathrm{CI}=1753-2193)$ versus $2312 \mathrm{~g}(95 \% \mathrm{CI}=2090$ - 
2534); $t=2.123 ; P>0.05$. When the birthweight difference was more than $500 \mathrm{~g}$, the greater would be the likelihood that the smaller twin would be second-born.

Table 1 showed that the incidence of birthweight discordance was 1.9 times higher in the year 2003 compared to the year $2000(\mathrm{P}>0.05)$. The frequency of birthweight discordance in twins appeared not to be influenced by maternal age [Table 2]. As shown in Table 3, grand multiparous mothers were at a significantly increased risk of delivery of growth-discordant twins compared to multiparous mothers $(P<0.01)$. The frequency of birthweight discordance according to sex pair is summarized in Table 4. Of the 65 same-sex twin pairs, 18 (27.7\%) had growth discordance, representing $60 \%$ of all cases of birth-weight discordance. Although the highest frequency $(33.3 \%)$ of birthweight discordance was among same-sex female twin pairs, it did not reach statistical significance. As shown in Table 5, the risk of occurrence of moderate and severe degrees

\begin{tabular}{|c|c|c|c|}
\hline $\begin{array}{l}\text { Year of } \\
\text { study }\end{array}$ & $\begin{array}{l}\text { Total no. of } \\
\text { live-born } \\
\text { twin pairs }\end{array}$ & $\begin{array}{l}\text { No. of } \\
\text { discordant } \\
\text { twin pairs }\end{array}$ & $\begin{array}{l}\text { Discordance } \\
\text { incidence } \\
(\%)\end{array}$ \\
\hline 2000 & 32 & 6 & 18.8 \\
\hline 2001 & 23 & 6 & 26.1 \\
\hline 2002 & 26 & 10 & 38.5 \\
\hline 2003 & 23 & 8 & 34.8 \\
\hline Total & 104 & 30 & 28.8 \\
\hline
\end{tabular}

Year of study: 2000 versus 2003: Z-statistic $=1.323 ; P>0.05$.

Table 2: Incidence of birthweight discordance by maternal age

\begin{tabular}{lccc}
$\begin{array}{l}\text { Maternal } \\
\text { age groups } \\
\text { (years) }\end{array}$ & $\begin{array}{c}\text { Total no. of } \\
\text { twin pairs }\end{array}$ & $\begin{array}{c}\text { No. of } \\
\text { discordant } \\
\text { twin pairs }\end{array}$ & $\begin{array}{c}\text { Discordance } \\
\text { incidence } \\
(\%)\end{array}$ \\
\hline$<20$ & 1 & 0 & 0 \\
$20-34$ & 81 & 25 & 30.9 \\
$\geq 35$ & 21 & 5 & 23.8 \\
Unknown & 1 & 0 & 0 \\
Total & 104 & 30 & 28.8 \\
\hline
\end{tabular}

Maternal age: $20-34$ years versus $\geq 35$ years: $Z$-statistic $=0.669$; $P>0.05$.

Table 3: Incidence of birthweight discordance by maternal parity

\begin{tabular}{lccc}
$\begin{array}{l}\text { Maternal } \\
\text { parity }\end{array}$ & $\begin{array}{c}\text { No. of twin } \\
\text { pairs }\end{array}$ & $\begin{array}{c}\text { No. of } \\
\text { discordant } \\
\text { twin pairs }\end{array}$ & $\begin{array}{c}\text { Discordance } \\
\text { incidence } \\
(\%)\end{array}$ \\
\hline 0 & 37 & 13 & 35.1 \\
$1-4$ & 62 & 14 & 22.6 \\
$\geq 5$ & 3 & 3 & 100 \\
Total & 104 & 30 & 28.8 \\
\hline Primipara versus multipara Z-statistic $=0.722 ; P>0.05$. & Multipara \\
versus grand multipara: $Z$-statistic $=6.924 ; P<0.01$.
\end{tabular}

Vol. 8, April-June, 2009 of birthweight discordance was 1.4 and 1.8 times, respectively, higher in twin mothers aged $20-34$ years compared to their counterparts aged 35 years and above $(P>0.05)$.

Comparing grand multiparous women with their multiparous counterparts, there was a 3 -fold increase in the risk of occurrence of the moderate level of birthweight discordance in the former [Table 6] $P>0.05$. The risk of the moderate level of birthweight discordance was 1.5 times higher in grand multiparous women compared to their primiparous counterparts $P>0.05$.

\begin{tabular}{lccc}
\hline $\begin{array}{l}\text { Table 4: Incidence of birthweight discordance by } \\
\text { sex pair }\end{array}$ & $\begin{array}{c}\text { Total no. of } \\
\text { twin pairs }\end{array}$ & $\begin{array}{c}\text { No. of } \\
\text { discordant } \\
\text { twin pairs }\end{array}$ & $\begin{array}{c}\text { Discordance } \\
\text { incidence } \\
(\%)\end{array}$ \\
\hline Sex pair & 39 & 12 & 30.8 \\
\hline $\begin{array}{l}\text { Different sex } \\
\text { Same sex } \\
\text { male }\end{array}$ & 32 & 7 & 21.9 \\
$\begin{array}{l}\text { Same sex } \\
\text { female }\end{array}$ & 33 & 11 & 33.3 \\
Total & 104 & 30 & 28.8 \\
\hline
\end{tabular}

Same sex versus different sex: $Z$-statistic $=0.171 ; P>0.05$. Same sex male versus same-sex female: $Z$-statistic $=0.360 ; P>0.05$.

Table 5: Level of birthweight discordance by maternal age

\begin{tabular}{lcccc}
\hline Maternal & Total no. & \multicolumn{3}{c}{ Levels of discordance (\%) } \\
\cline { 3 - 5 } $\begin{array}{l}\text { age } \\
\text { (years) }\end{array}$ & $\begin{array}{c}\text { of twin } \\
\text { pairs }\end{array}$ & $\begin{array}{c}15-24.9 \\
\text { (moderate) }\end{array}$ & $\begin{array}{c}25-34.9 \\
\text { (severe) }\end{array}$ & $\begin{array}{c}35 \text { or } \\
\text { more } \\
\text { (extreme) }\end{array}$ \\
\hline$<20^{\text {a }}$ & 1 & $0(0)$ & $0(0)$ & $0(0)$ \\
$20-34^{b}$ & 81 & $16(19.8)$ & $7(8.6)$ & $2(2.5)$ \\
$\geq 35^{c}$ & 21 & $3(14.3)$ & $1(4.8)$ & $1(4.8)$ \\
Unknown & 1 & $0(0)$ & $0(0)$ & $0(0)$ \\
Total & 104 & $19(18.3)$ & $8(7.7)$ & $3(2.9)$ \\
\hline
\end{tabular}

Figures in parentheses are percentages of level of discordance. Moderate level of discordance: $b$ versus $c ; Z$ - statistic $=0.623$; $P>0.05$. Severe level of discordance: $b$ versus $c ; Z$-statistic $=0.677 ; P>0.05$. Extreme level of discordance: $b$ versus $c$; $Z$-statistic $=0.462 ; P>0.05$.

Table 6: Level of birthweight discordance by maternal parity

\begin{tabular}{|c|c|c|c|c|}
\hline \multirow{2}{*}{$\begin{array}{l}\text { Maternal } \\
\text { parity }\end{array}$} & \multirow{2}{*}{$\begin{array}{c}\text { Total no. } \\
\text { of twin } \\
\text { pairs }\end{array}$} & \multicolumn{3}{|c|}{ Levels of discordance (\%) } \\
\hline & & $\begin{array}{c}15-24.9 \\
\text { (moderate) }\end{array}$ & $\begin{array}{l}25-34.9 \\
\text { (severe) }\end{array}$ & $\begin{array}{c}35 \text { or } \\
\text { more } \\
\text { (extreme) }\end{array}$ \\
\hline $0^{d}$ & 37 & $10(27.0)$ & $3(8.1)$ & $0(0)$ \\
\hline $1-4^{e}$ & 62 & $8(12.9)$ & $4(6.5)$ & $2(3.2)$ \\
\hline$\geq 5^{f}$ & 5 & $2(40.0)$ & $0(0)$ & $1(20.0)$ \\
\hline Total & 104 & $20(19.2)$ & $7(6.7)$ & $3(2.9)$ \\
\hline \multicolumn{5}{|c|}{$\begin{array}{l}\text { Figures in parentheses are percentages of level of discordance. } \\
\text { Moderate level of discordance: } d \text { versus e; } Z \text {-statistic }=1.669 ; \\
P>0.05 . \text { Moderate level of discordance: } \text { e versus } f ; Z \text {-statistic } \\
=1.214 ; P>0.05 . \text { Severe level of discordance: } d \text { versus e; } \\
Z \text {-statistic }=0.292 P>0.05 . \text { Extreme level of discordance: e } \\
\text { versus f; } Z \text {-statistic }=0.932 ; P>0.05 \text {. }\end{array}$} \\
\hline
\end{tabular}




\section{Discussion}

The present study further confirms the report of a previous study ${ }^{[1]}$ that the frequency of birthweight discordance in twin gestation depends on the definition used. For instance, the prevalence of twin pairs with birthweight discordance was $28.8 \%$ when $15 \%$ cut-off point was used but dropped to $9.6 \%$ when $25 \%$ cut-off point was applied. The prevalence $(28.8 \%)$ reported here is higher than the $16.9 \%$ reported from Israel by Blickstein et al, ${ }^{[1]}$ using the same $15 \%$ cut-off point, suggesting a higher prevalence among Nigerian twins. The reason for this difference in prevalence is not clear. It is possible that the high incidence of anemia in pregnancy and chronic malnutrition in developing countries, ${ }^{[11]}$ may result in lower combined twin birthweight among Nigerian mothers compared to their Israeli counterparts. It has been shown that the lower the combined twin birthweight, the higher the frequency of delivery of birthweight-discordant twins. ${ }^{[3,2]}$ On the other hand, when $25 \%$ cut-off point was applied, our frequency $(9.6 \%)$ compared favorably with $9.3 \%$ reported by Ekure and Iroha ${ }^{[16]}$ in Lagos, Nigeria. Further comparison was not possible because the authors of the Lagos study did not state the prevalence using $15 \%$ as a cut-off point.

Data from the present study indicated that the risk of delivery of growth-discordant twin pairs was significantly higher in grand multiparous women compared to their multiparous counterparts. Primiparous mothers also tended to deliver growthdiscordant twins more often than their multiparous counterparts, although the difference did not reach statistical significance. Similar findings have been reported by other investigators. ${ }^{[12-14]}$ From this finding, it would appear that the uteri of multiparous women were more efficient in nurturing twins compared to those of their primiparous counterparts. As a consequence, multiparous women were more likely to deliver larger twins with higher combined twin birthweight. This is in keeping with the report of Blickstein et al, ${ }^{[3,15]}$ which showed that the higher the combined twin birthweight the less likely it was to deliver discordant pairs. In that report, they stated that the uteri that can efficiently nurture twins are associated with increased combined twin birthweight and decreased discordant frequencies. ${ }^{[15]}$ In the case of grand multiparous women, it is possible that the higher number of previous deliveries, especially if in quick succession, may have exhausted these women nutritionally leading to intrauterine malnutrition and hence lower combined twin birthweight. As a consequence, the risk of delivery of birthweight-discordant infants is increased. A previous study in the same hospital had shown that the frequency of delivery of low birthweight infants by grand multiparous women was relatively high. ${ }^{[17]}$ Although same-sex twin pairs accounted for $60 \%$ of all cases of birthweight discordance, the difference was not statistically significant. Other investigators ${ }^{[3,18]}$ have reported similar higher frequency of discordance in same-sex twin pairs, suggesting that birthweight in females may be influenced by a male co-twin, resulting in decreased frequency of intrapair birthweight discordance in different-sexed twin pairs. In this regard, Rydhstroem ${ }^{[19]}$ reported that fetal loss was two times higher in the same-sex compared to different-sex twin pairs and only in the same-sexed pairs was fetal loss significantly correlated with birthweight discordance. The clinical implication was that discordance was more important to fetal well-being in the same-sex than in different-sex twin pairs. The present study indicated that more discordant-second pair was associated with the larger birthweight difference (more than $500 \mathrm{~g}$ ). Similar findings have been reported by other investigators, ${ }^{[20]}$ suggesting that the larger the weight disparity, the greater the likelihood that the smaller twin will be second born. It would, therefore, appear that the birth order of the heavier twin was an integral part of the discordance phenomenon. Although several investigators ${ }^{[20-22]}$ have shown that first-born twins were not always heavier than their second-born siblings, data from the present study suggested that second-born twins have only 1.2 times the risk of being the lighter baby when there is at least $25 \%$ discordance between twin pairs. There is no readily available explanation for this finding.

In conclusion, birthweight discordance is common in twin gestations in Benin City, especially among grand multiparous women. It is, therefore, recommended that all twin gestations, particularly in grand multiparous women, should be evaluated for growth discordance and when diagnosed should be observed closely. Prevention of pregnancy in grand multiparous women, using family-planning methods, is advocated.

\section{References}

1. Blickstein I, Shoham-Schwartz Z, Lancet M, Borenstein R. Characterization of growth-discordant twins. Obstet Gynecol 1987;70:11-5.

2. Erkkola R, Al-Mello S, Piiroinen O, Kero P, Sillap M. Growth discordancy in twin pregnancies: A risk factor not detected by measurement of biparietal diameter. Obstet Gynecol 1985;66:203-6.

3. Blickstein I, Goldman RD, Smith-Levitin M, Greenberg $M$, Sherman $D$, Rydhstroem $H$. The relation between inter-twin birth weight discordance and total twin birth weight. Obstet Gynecol 1999;93:113-6.

4. Hollier LM, Mclntire DD, Leveno KJ. Outcome of twin pregnancies according to intrapair birth weight differences. Obstet Gynecol 1999;94:1006-10. 
5. Spellacy WN, Handler A, Ferre CD. A case-controlled study of 1,253 twin pregnancies from a 1982-1987 perinatal data base. Obstet Gynecol 1990;75:168-71.

6. Blickstein I, Lancet M. The growth discordant twin. Obstet Gynecol Surv 1988;43:509-15.

7. Cheung VY, Bocking AD, DaSilva OP. Preterm discordant twins: What birth weight difference is significant? Am J Obstet Gynecol 1995;172:955-99.

8. Babson SG, Phillips DS. Growth and development of twins dissimilar in size at birth. N Engl J Med 1973;289:937-42.

Page | 114

9. Blickstein I. The definition, diagnosis and management of growth discordant twins: An international census survey. Acta Genet Med Gemellol Roma 1991;40:345-51.

10. Onyiriuka AN. Trend in birth weight of babies born in Benin City, Nigeria. Ann Biomed Sci 2002;1:148-51.

11. Guashio S, Spinillo A, Stola E, Pesuado PC. Growth retardation, size at birth and perinatal mortality in twin pregnancy. Int J Gynecol Obstet 1987;25:399-403.

12. Fakeye 0 . Twin birth weight in Nigeria and the effect of sex-pair and parity. Trop Geogr Med 1986;38:265-70.

13. Blickstein I, Zalel Y, Weissman A. Pregnancy order: A factor influencing birth weight in twin gestations. J Reprod Med 1995;40:443-6.

14. Rydhstroem H. A birthweight-for-gestation standard based on 4,737 twins born in Sweden between 1983 and 1985. Acta Obstet Gynecol Scand 1992;71:506-11.
15. Blickstein I, Goldman RD, Mazkerath R. Adaptive growth restriction as a pattern of birthweight discordance in twin gestations. Obstet Gynecol 2000;96:986-90.

16. Ekure EN, Iroha EO. Perinatal mortality among twins in Lagos University Teaching Hospital: Associated risk factors. Nig Qt J Hosp Med 2002;12:21-5.

17. Onyiriuka AN. Trends in incidence of delivery of low birthweight infants in Benin City, Southern Nigeria. Niger Postgrad Med J 2006;13:189-93.

18. Glinianaia SV, Mangus $P$, Harris JR, Tambs K. Is there a consequence for fetal growth of having an unliked-sexed cohabitant in utero? Int J Epidemiol 1998;27:657-9.

19. Rydhstroem H. Discordant birth weight and late fetal death in like-sexed and unlike-sexed twin pairs: A population-based study. Br J Obstet Gynaecol 1994;101:765-9.

20. Friedman EA, Schteleben MR, Friedman LM. Relative birth weights of twins. Obstet Gynecol 1977;49:717-20.

21. Ilesanmi AO, Obisesan KA, Aronojolu AO, Fawole O, Robert AO. Relative birth weights in twins. Niger Med J 2000;38:14-5.

22. Nantu SN, Kayode Y. Relative birth weight in twins. Int J Gynecol Obstet 1983;21:377-80.

Source of Support: Nil, Conflict of Interest: None declared. 